\title{
Improving Economic Management Decisions in Forestry with the SorSim Assortment Model
}

\author{
Renato Lemm, Clemens Blattert, Stefan Holm, Leo Bont, Oliver Thees
}

\begin{abstract}
The sustainable supply of timber is one of the most important forest ecosystem services and a decisive factor determining the long-term profitability of forest enterprises. If timber production is to be economically viable, there must always be a way to analyse forest stands and trees felled for exploitation with regard to the wood assortments they contain. Only then can the expected timber yields, achieved by various silvicultural strategies or actions and different sorting options, be quantified with sufficient accuracy. The SorSim assortment simulator was developed for forest practitioners and forest scientists in Switzerland to realistically simulate the sorting of individual trees and entire forest stands based on defined specifications. SorSim has a simple user interface and comes in a number of different language versions $(G, E, F)$. The software is implemented in Java, making it platform-independent. It can be downloaded for free at (https://www.wsl.ch/en/projects/sortimentsimulator-sorsim.html). This article provides an overview of how the simulator works and demonstrates its potential applications based on a practical and a scientific example. A particular practical advantage is that the composition of the assortments of the planned harvests can be estimated according to quantity and value. When used in strategic planning and especially in research, SorSim provides a basis for analysing either long-term developments in yields from forest stands or silvicultural treatment methods. Based on an even-aged and a selection forest stand, the scientific example shows how strongly the assessment of the advantageousness of two different silvicultural strategies depends on the time when the calculation was made (using historical and current assortment revenues and timber harvesting costs). In particular, the combination of SorSim with timber harvest productivity models enables differentiated forest economic insights. Various approaches for value-based optimisation in the sorting of individual trees and for the optimal allocation of harvesting activities to defined customer demands are currently being examined as further SorSim developments.
\end{abstract}

Keywords: decision support, forest economics, forest management planning, net present value, timber revenues

\section{Introduction}

Sustainable timber production, along with all other ecosystem services that forests provide to society, remains an important forest management objective (Forest Europe 2015, EASAC 2017). Furthermore, timber provision is the most important source of revenue for forest enterprises: sufficient provision guarantees their favourable long-term economic performance, which in turn enables them to provide a wide range of other important ecosystem services (Rigling and Schaffer 2015, Bürgi et al. 2018). However, economic efficiency presupposes the selection of appropriate, cost-effective timber harvesting methods and, at the same time, the adoption of silvicultural strategies that deliver the products in demand.

Consequently, the precise forecasting of costs and revenues from forest managements pursuing different strategies is a prerequisite for optimising the mid- and long-term planning of efficient timber production 
(Möhring 2010, Hanewinkel et al. 2014a, Härtl et al. 2016, Blattert et al. 2017). There are various economic methods in forestry for assessing the long-term economic viability of different silvicultural treatment strategies and timber harvesting measures. Many of these methods are derived from the field of investment planning (Klemperer 1996, Navarro 2003), such as the net present value (NPV) method (Fürstenau et al. 2007, Seidl et al. 2007, Pukkala 2016), the land expectation value (LEV) method or Faustmann formula (Hanewinkel et al. 2010, Hanewinkel et al. 2013, Nölte et al. 2018), and the annuity method (Möhring and Rüping 2008, Hanewinkel et al. 2014a, Blattert et al. 2018). However, the economic viability of any harvesting activity also has to be accurately calculated within the framework of short-term planning. Such a preliminary calculation also provides a solid basis for forest owners' negotiations with timber harvesting service providers and timber buyers, as well as for controlling timber transport.

In both long-term and short-term forest management planning, the costs of timber harvesting and the revenues from marketable products need to be quantified using models. This pre-costing covers three areas:

$\Rightarrow$ estimating the quantity of timber harvested per tree species and timber assortment

$\Rightarrow$ determining timber revenues for the expected products and quantities

$\Rightarrow$ deriving timber harvesting costs for the underlying conditions (i.e. topography, harvesting regime).

In Switzerland, there are computer based models for calculating timber harvesting costs (point 3), including the timber harvesting productivity model $\mathrm{HeProMo}^{1}$ (Frutig et al. 2009). The marketable products can be determined by estimating the potential assortments (point 2) in individual trees. Particularly suitable for this purpose are IT-supported models which, based on just a small amount of information, such as tree species, diameter at breast height (DBH) and age (or height), simulate the stem forms of individual trees, match trees with given assortments and determine their volumes. In Germany, instruments already exist for this purpose and are implemented with the models Holzernte 8.1 (FVA 2013) and WaldPlaner (Hansen and Nagel 2014). In addition, the SorSim 2.0 assortment simulator is now available in Switzerland for this purpose. SorSim is a software for

\footnotetext{
${ }^{1}$ www.wsl.ch/en/services-and-products/software-websites-and-apps/hepromo.html (May 2018)
}

practitioners and can be used in other applications to calculate freely definable assortments for different tree species and the expected timber revenues. The software was developed at the Swiss Federal Institute for Forest, Snow and Landscape Research (WSL). A first prototype of the SorSim assortment simulator was designed and implemented by Lemm and Erni (2009). In 2012 it was reimplemented in Java as version 2.0 (Holm et al. 2012). SorSim now supports the display languages German, French and English. The user manual provides a detailed description of all its functions and the underlying calculation methods (Holm et al. 2012).

This article has two aims. The first is to describe the fundamentals and the methodological concept of Sor$\mathrm{Sim}$. This includes the description of the required input data, methods for modelling the stem form, criteria and requirements for dividing the stem and recording its quality and revenues, and algorithms for classifying the stem into assortments. The second aim is to demonstrate how SorSim can be applied in both practice and research. The practical example shows how a list of trees can be sorted and analysed to determine the assortments of each individual tree. The research example uses two experimental plots (an evenaged stand and a selection stand) to analyse how strongly an assessment of the advantages and disadvantages of two different silvicultural strategies depends on the time at which the evaluation is made. Based on historical and current cost approaches, timber prices and harvesting productivity, the profitability of an even-aged stand is compared with that of a selection stand.

\section{Material and Methods}

\subsection{How Does the Assortment Simulator Work?}

\subsubsection{Basic Method}

With the SorSim assortment simulator, a list of trees can be sorted into marketable assortments according to a range of specifications. A gross timber revenue can thus be calculated on the basis of quality percentages and timber prices.

The classification of a given tree into assortments takes place at the stem base, starting with a variable stump height (default $=30 \mathrm{~cm}$ ). The algorithn then checks whether an assortment has the required midor top-diameter specifications. Assortments are assigned in the order set out in the selected sorting strategy, usually taking the strongest and most valuable assortments first. Consequently, SorSim does not yet optimise the value of an entire forest stand. Once a 
suitable position for an assortment is found, the volume of the piece is determined. Incremental attempts are made (e.g. in $50 \mathrm{~cm}$ steps) to lengthen the assortment as much as possible within the limits of its defined dimensions. Next, the resulting assortment is processed and, taking into account any additional length, a new position on the stem is marked for the next assortment.

SorSim currently designates all parts of the tree unsuitable for use as stem wood (e.g. tree crown). Owing to their expansive crowns, deciduous trees are only divided into saw wood up to the base of the crown. The crown base for the different tree species is calculated according to Döbbeler (2002). The volume determination of the tree stem is based on the rotational body of the stem form around its vertical axis. A cubic spline interpolation can be used to model the stem form based on the solid empirical database of almost 40,000 individual trees measured in the Swiss National Forest Inventory (NFI) (Brassel and Lischke 2001). The input variables are tree height, tree species, diameter at breast height (DBH) and diameter at a height of $7 \mathrm{~m}(\mathrm{~d} 7 \mathrm{~m})$. If measured values are not available, $\mathrm{d} 7 \mathrm{~m}$ can alternatively be calculated based on the form quotient $\mathrm{d} 7 \mathrm{~m} / \mathrm{DBH}$ derived from NFI surveys. This very precise spline function was used in the following examples. Another option would be to use the stem form function described by Lemm (1991). This

Table 1 Assortment specifications implemented in SorSim currently consider the Swiss assortment guidelines for raw timber (Waldwirtschaft Schweiz 2010). The timber is mainly categorised according to its dimensions, based on the mid-diameter of the cut trees. Tree lengths are classified into: short timber $\mathrm{L} 1(3.0-6.0 \mathrm{~m})$, medium-long timber $\mathrm{L} 2(6.5-14.5 \mathrm{~m})$ or long timber $\mathrm{L} 3(15.0-22.0$ $\mathrm{m})$. Deciduous wood is only classified as short timber L1

\begin{tabular}{|c|c|c|}
\hline Classes & Mid-diameter & Minimum top diameter, only for L3 \\
\hline 6 & $\geq 60 \mathrm{~cm}$ & $22 \mathrm{~cm}$ \\
\hline 5 & $50-59 \mathrm{~cm}$ & $22 \mathrm{~cm}$ \\
\hline 4 & $40-49 \mathrm{~cm}$ & $22 \mathrm{~cm}$ \\
\hline $3 \mathrm{~b}$ & $35-39 \mathrm{~cm}$ & $18 \mathrm{~cm}$ \\
\hline $3 \mathrm{a}$ & $30-34 \mathrm{~cm}$ & $18 \mathrm{~cm}$ \\
\hline $2 \mathrm{~b}$ & $25-29 \mathrm{~cm}$ & $18 \mathrm{~cm}$ \\
\hline $2 \mathrm{a}$ & $20-24 \mathrm{~cm}$ & $18 \mathrm{~cm}$ \\
\hline $1 \mathrm{~b}$ & $15-19 \mathrm{~cm}$ & $14 \mathrm{~cm}$ \\
\hline $1 \mathrm{a}$ & $10-14 \mathrm{~cm}$ & - \\
\hline 0 & $<10 \mathrm{~cm}$ & - \\
\hline
\end{tabular}

function models the stem form of trees using species and $\mathrm{DBH}$ as the only attributes, according to Grundner and Schwappach (1952). Bark functions are based on investigations by the Forest Research Institute of Baden-Württemberg (FVA) (Altherr 1974). The functions described by (Badoux 1979) are finally used to deduce the volume of bark.

The assortment specifications used to classify trees are currently based on the Swiss assortment guidelines for raw timber (Table 1) (Waldwirtschaft Schweiz 2010). These classes can be modified in the assortment specification file. Furthermore, the maximum top diameter up to which round timber is sorted can be set, as well as the minimum diameter below which stem sections are to be designated as class zero (for energyrelated or material use). However, alongside the assortment specifications for Switzerland, it is also a simple matter to implement other country-specific assortment guidelines for raw timber.

The assortment prices and quality proportions per assortment specified in the model can also be amended as required. The specified assortment prices currently set as default values are based on prices recommended in Switzerland in the forest year 2017/2018. Quality proportions are based on empirical values from the WSL research forest at Wagenrain (in the canton of Aargau) (Rosset et al. 2009). Timber revenues from each tree are calculated based on each assortment quantity, price and quality proportion.

\subsubsection{User Interface}

On the main screen of SorSim, the »Fit assortment in tree list « sub-application consists of the panels »Tree list «, »Timber assortment specification «, »Expression of results« and »Summary of the results« (Fig. 1). Based on the required input variables, the stem forms of a set of trees are modelled and divided into a set of assortments. In the »Tree list « panel, a list of trees is entered as input from a CSV file. This is where individual trees are listed, along with their DBH and, if known, height and $\mathrm{d} 7 \mathrm{~m}$. In the »Timber assortment specification « panel, the classification criteria are defined in an external CSV file, in line with country-specific requirements. The main criteria used for dimension sorting are stem length and mid- and top-diameter. The assortment list is created in the »Expression of results « submenu (Fig. 1). By ticking the »Write generated assortment list to the following output file « check box, assortments can be exported in CSV format to a freely chosen output file. A summary of the assortments is displayed in the text box in the "Summary of the results « panel. Further details can be found in the user manual (Holm et al. 2012). 


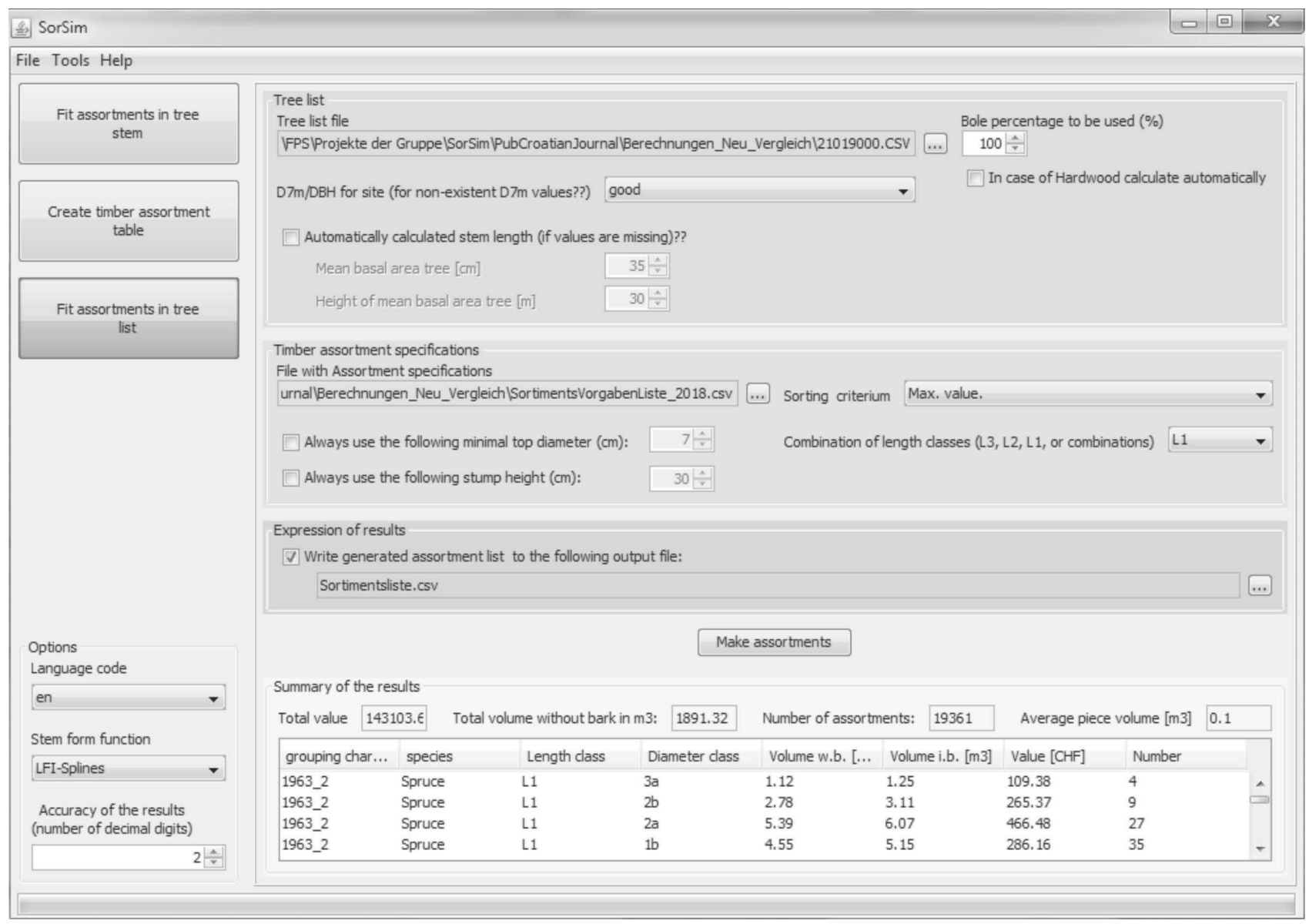

Fig. 1 Screenshot of the SorSim assortment simulator (sub application: „Fit assortment in tree list»)

\subsection{Typical Applications and Database}

The following two examples of applications from forest practice (Section 2.2.1) and research (Section 2.2.2) demonstrate possible use cases of SorSim.

\subsubsection{Example 1 - Tree-List-Pased Sorting}

In this first example of a SorSim use case, assortments and their corresponding revenues were calculated based on the tree list of a scheduled harvesting operation. A question frequently arising in practice is: Which assortments and gross harvesting revenues can be expected if a given stand of Norway spruce (Picea abies L.), silver fir (Abies alba M.), European beech (Fagus sylvatica L.) and European ash (Fraxinus excelsior L.) trees are harvested? The input data required by SorSim was a list of the stand to be harvested in which the trees to be felled were recorded, specifying their species and DBH.

In the »Fit assortment in tree list« sub-application, SorSim expects a list of trees to be divided into assortments (Fig. 1). Such a tree list is a csv file with a spe- cific structure (Fig. 2). Comment lines always start with $\mathrm{a} » \# \ll$ and are ignored by the application. Each tree to be assigned to an assortment is defined in a separate line. The file can contain an arbitrary number of comment lines and tree definitions.

\subsubsection{Example 2 - Comparison of Selection Stands and Even-Aged Stands}

The second example was a scientific analysis of strategic planning for two differently treated silvicultural stands. The optimal use of resources is a claim of the economic principle (Möhring 2010) and thus a question for which science can provide useful assistance in answering. The question in this example was: How does an area of selection forest differ from an area of even-aged forest in terms of assortment yield and net revenue as a function of distinct cost and revenue situations? There is currently no uniform picture of the conditions under which a selection stand can prove financially more successful than an even-aged high forest (Knoke 2009). Our research example cannot close this knowledge gap directly, but the results 


\begin{tabular}{|c|c|c|c|c|c|c|c|}
\hline \multicolumn{8}{|c|}{ \# 11.03.2018/RL } \\
\hline \multicolumn{8}{|c|}{ \# File with tree list for assortment simulator } \\
\hline \multicolumn{8}{|c|}{ 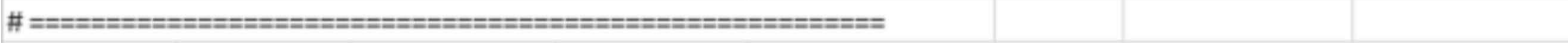 } \\
\hline \#ID & tree species & tree-code & description & date of recording & DBH & diameter in $7 \mathrm{~m}$ & stemlength $\mathrm{m}$ \\
\hline 1 & spruce & 100 & spruce_1_1 & 2012 & 18 & 0 & 0 \\
\hline 9 & spruce & 100 & spruce_1_9 & 2012 & 22 & 0 & 0 \\
\hline 16 & spruce & 100 & spruce_1_16 & 2012 & 26 & 0 & 0 \\
\hline 19 & spruce & 100 & spruce_1_19 & 2012 & 30 & 0 & 0 \\
\hline 22 & spruce & 100 & spruce_1_22 & 2012 & 34 & 0 & 0 \\
\hline 33 & spruce & 100 & spruce_1_33 & 2012 & 50 & 0 & 0 \\
\hline 38 & fir & 101 & fir_1_1 & 2012 & 14 & 0 & 0 \\
\hline
\end{tabular}

Fig. 2 Example of a list with trees that will be allocated into marketable products using the assortment simulator SorSim

in this example do highlight how revenue-based and cost-based approaches influence the advantage of an even-aged stand compared to a selection forest.

The research example was based on an extensive series of measurements taken at two experimental forest yield test sites in Switzerland: an even-aged stand and a selection stand. Table 2 displays the basic characteristics of both stands and other information relevant to their management.

The even-aged stand with an average volume increase of $18.5 \mathrm{~m}^{3} \mathrm{a}^{-1}$ ha ${ }^{-1}$ was situated on a more fertile site than the selection stand with an average volume increase of $9.7 \mathrm{~m}^{3} \mathrm{a}^{-1} \mathrm{ha}^{-1}$ due to the sea level. The selection stand was first inventoried in 1928, the even-aged stand in 1888. In these two inventories, the DBH and tree height of the stand to be felled and of the remaining stand were recorded. SorSim used cubic spline interpolation to calculate the stem form of each tree, with and without bark, from the $\mathrm{DBH}, \mathrm{d} 7 \mathrm{~m}$ and tree height (Brassel and Lischke 2001). The trees were divided into assortments as short timber (L1), in line with the Swiss timber assortment guidelines (Waldwirtschaft Schweiz 2010).

In each case, the assortments and revenues of each stem were calculated for different tree species and at different inventory times. The harvest net revenues of the stand to be felled and of the remaining stand were ascertained based on the total yields of all trees and the timber harvesting costs incurred, which were calculated with HeProMo. This produced accurate overviews over 70 to 90 years of the stands existence and their management (even-aged or selection), based on measurements of single stems. Once the revenue and cost situations for the stands are calculated, they can be compared in terms of their economic efficiency, and the strategies for treating them can then be assessed. Niederer and Bill (2015) showed that nominal timber prices in 2015 were only half as high as they had been in 1969, whereas the labour costs for timber harvesting had doubled. Naturally, this has consequences for assessing the profitability of a silvicultural strategy. The analysis in this example also included an examination of how the assessment of the two strategies had changed between historical and modern-day considerations.

In the example, the regeneration costs for the evenaged stand in the first 15 years were assumed to be $4800 \mathrm{CHF} \mathrm{ha}^{-1}$ in 1969 and 24,000 CHF ha ${ }^{-1}$ in 2018, considering the costs for planting and tending. Due to the continuous natural regeneration, no planting costs were taken into account for the selection stand (Table 2 ). The nominal timber prices were defined per assortment for the year 2018 and the price and quality shares were based on the experience of a Swiss forest enterprise (Table 3). For the year 1969, the nominal timber prices were taken from the period 1919 to 2014 for Switzerland (average for short timber) (Niederer and Bill 2015). The allocation of timber prices by assortment in 1969 was based on a proportionality factor that was derived from the nominal timber price of 2018. The nominal full costs for 1969 were taken from a time series (1966 to 2017) of a Swiss forest enterprise (Anon. 2018) and are compareable to those of Niederer and Bill 2015.

The cost of timber harvesting in 1969 was calculated using the older HeProMo models for »motormanual felling and processing « and »skidding « (Frutig et al. 2009). These models are based on data from the 1970s. By contrast, 2018 harvesting costs were calculated using updated HeProMo models based on data from 2014-2016. Harvesting of the even-aged stand would probably be fully mechanised in 2018, and thus the timber harvesting costs were also simulated using the HeProMo harvester and forwarder models. The 
input variables for HeProMo were the proportions of tree species, mean tree volume, skidding distances and costs per hour for personnel and machinery.

The Net Present Value (NPV) was used to compare the sylviculatural strategies under the distinctive price and cost situations (Klemperer 1996). The NPV depends on the selected discount rate, which assumes a temporal preference for cash flows and gives less importance to future events. For this example, the NPV was calculated for the discount rates of $1 \%$ and $3 \%$. The starting point for the caculations was the time of stand establishment for the even-aged and the first inventory for the selection stand (Table 1). For each stand, the NPV was calculated along the inventory time steps.

$$
N P V=-P+\sum_{\mathrm{t}=1}^{\mathrm{n}} \frac{R_{\mathrm{t}}-C_{\mathrm{t}}}{(1-i)^{\mathrm{t}}}+\frac{L V_{\mathrm{n}}}{(1+i)^{\mathrm{n}}}
$$

Where:
$N P V$ net present value
$P \quad$ cost for planting and tending
$R$ timber revenue at inventory time step, $\mathrm{t}$
$C$ harvesting cost at inventory time step, $\mathrm{t}$
$L V$ liquidation value of stand at end of inventory, $\mathrm{n}$
i discount rate, $1 \%, 3 \%$

\section{Results and Discussion}

\subsection{Example 1: Tree-List-Based Sorting}

The aim of the first example was to compute assortements and their corresponding revenues of a scheduled harvesting operation. Based on the csv file, which consists of a list of trees to be sorted, users can create their own graphics. Fig. 3a shows the diameter distribution of the tree list that was divided into as-

Table 2 Description of the two long-term experimental plots investigated in the scientific application example. In both plots, the harvested and the remaining stands were measured in each inventory

\begin{tabular}{|c|c|c|}
\hline Characteristic & Even-aged stand & Selection forest (Plenterwald) \\
\hline Permanent observation area number & $21,019,000$ & $1,041,000$ \\
\hline Location, elevation (m a.s.I.) & Olten, 445 & Rougemont Les Arses, 1294 \\
\hline Size, ha & 0.25 & 1.50 \\
\hline Establishment of stand, year & 1867 & Continuously since 1928 \\
\hline First inventory, year & 1888 & 1928 \\
\hline Last inventory, year & 1963 & 2013 \\
\hline Initial growing stock (first inventory), $\mathrm{m}^{3} / \mathrm{ha}$ & 188 & 367 \\
\hline Proportions of tree species, $\%$ & 100 spruce (Picea abies) & $\begin{array}{l}\text { first inventory: } 60 \text { spruce (Picea abies), } 40 \text { fir (Abies alba) } \\
\text { last inventory: } 40 \text { spruce, } 60 \text { fir }\end{array}$ \\
\hline Number of inventories, $\mathrm{n}$ & 14 & 14 \\
\hline Time between two inventories, years & $4-14$ & $4-10$ \\
\hline Planting and treatment costs during first 15 years, CHF/ha & 24,000 & none \\
\hline
\end{tabular}

Table 3 Sources and assumptions for timber prices and harvesting costs

\begin{tabular}{|c|c|c|c|}
\hline Year & 1969 & \multicolumn{2}{|c|}{2018} \\
\hline Source of timber revenue & $\begin{array}{l}\text { Historic timber price series from } 1919 \text { to } 2014 \\
\text { (Niederer and Bill 2015) }\end{array}$ & \multicolumn{2}{|c|}{$\begin{array}{l}\text { Recommendations for roundwood sales 2017/2018 } \\
\text { (www.waldaargau.ch, May 2018) }\end{array}$} \\
\hline $\begin{array}{l}\text { Defined harvesting regimes of } \\
\text { HeProMo, (timber harvest data on } \\
\text { which the model was derived) }\end{array}$ & $\begin{array}{l}\text { 'Motor-manual felling' and 'skidding } \\
\text { with skidder', data basis 1970s }\end{array}$ & $\begin{array}{l}\text { 'Motor-manual felling' and 'skidding } \\
\text { with skidder', data basis 2014-2016 }\end{array}$ & $\begin{array}{l}\text { 'Felling with harvester' and 'skidding } \\
\text { with forwarder', data basis 2014-2016 }\end{array}$ \\
\hline Source for harvesting costs & $\begin{array}{l}\text { Staff } 9 \text { CHF/ha, chainsaw } 7 \text { CHF/ha, } \\
\text { skidder } 40 \text { CHF/ha } \\
\text { (Niederer and Bill 2015, Anonymous 2018) }\end{array}$ & $\begin{array}{c}\text { Staff } 70 \text { CHF/ha, chainsaw } 14 \text { CHF/ha, } \\
\text { skidder } 100 \text { CHF/ha } \\
\text { (www.fus-efs.ch, May 2018) }\end{array}$ & $\begin{array}{c}\text { Staff } 70 \text { CHF/ha, harvester } 240 \text { CHF/ha, } \\
\text { forwarder } 120 \text { CHF/ha } \\
\text { (www.fus-efs.ch, May 2018) }\end{array}$ \\
\hline
\end{tabular}



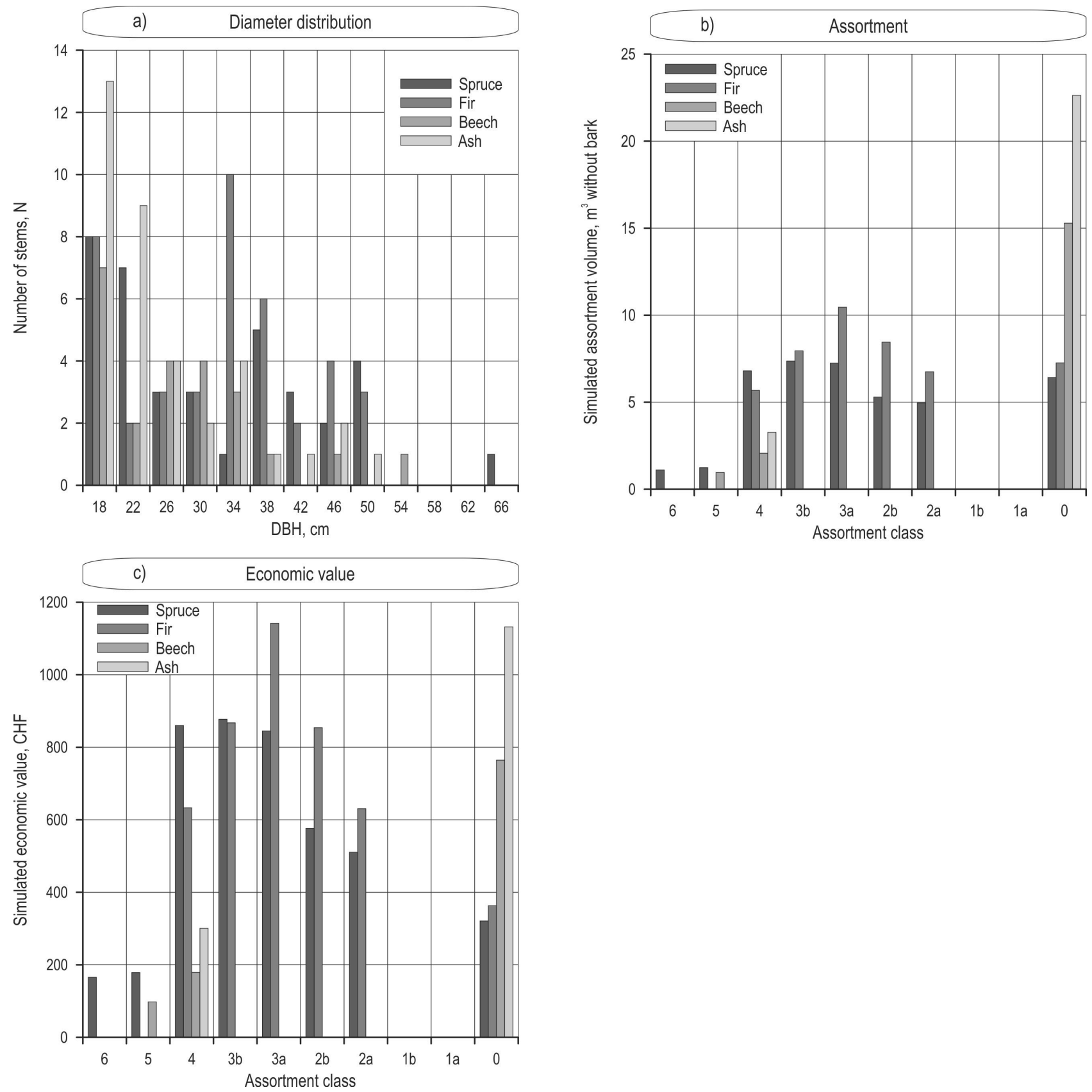

Fig. 3 (a) Diameter distribution of the tree list used as csv-input for SorSim. (b) Simulated assortment volumes $\left(\mathrm{m}^{3}\right.$, without bark) of the class $\mathrm{L} 1$ with a length of 3-6 $\mathrm{m}$. (c) Simulated economic value (CHF) of assortments based on current assortment prices per $\mathrm{m}^{3}$ (see Table 1)

sortments in the first example. As displayed in Fig. 3b, assortments were allocated as saw wood up to category 4 for beech and ash, and up to category 2 for softwood. The remainder was sorted as residual timber (category 0), used for energy wood. For deciduous species, stem wood was only sorted up to the crown base. Thus, for beech a considerable amount of timber ends up as energy wood. Only a few cubic metres of round timber fell into category 4 or 5 . Roughly the same proportion of timber from ash trees fell into category 4. Most spruce timber fell into category 3 or 4 , and most fir fell into category 2 or 3.

The calculated revenues indicate that conifer species can be expected to make a large contribution to the financial result (Fig. 3c). The assortment simulator gives forest practitioners a way to designate assortments 
according to their chosen sorting strategy, compare variants and improve the economic efficiency of timber use. The instrument efficiently determines this specific information.

Apart from the practical example described here, SorSim was also tested with three forest enterprises using specific harvesting activities. In most cases, these tests were situated in spruce-dominated forest stands. However, the tests also included stands of fir, larch, beech and other hardwood species. The expected assortments were calculated based on tree lists. After felling, the results of the timber inventory were compared with the calculations. Comparison of the final processed assortments with preliminary calculations from SorSim showed good correlation, though occasional deviations occurred for all tree species. In most instances, these cases could be explained by the history of the respective forest stand and its associated structural and qualitative consequences.

\subsection{Example 2: Comparison of a Selection Stand and an Even-Aged Stand}

The target of example two was an economic analysis of differently treated stands. When interpreting the results of this example, it should be noted that the value of the even-aged stand has accrued over a period of 96 years, as opposed to a period of just 85 years for the selection stand.

Figs. $4 \mathrm{a}$ and $4 \mathrm{~b}$ show the effects of sylvicaltural strategies and the distinctive revenues and cost situations and the NPV.

$\Rightarrow$ In the year 1969, the NPV was clearly higher in the selection stand than in the even-aged stand, under both a discount rate of $1 \%$ and $3 \%$. At a discount rate of $1 \%$, the selection stand reached a value of $84,560 \mathrm{CHF} \mathrm{ha}^{-1}$ after 85 years. The corresponding value in the even-aged stand was 43,249 $\mathrm{CHF} \mathrm{ha}{ }^{-1}$ after 96 years. The selection stand further showed a continous increase right from the beginning, whereas the NPV of the even-aged stand remained almost constant until year 40 .

$\Rightarrow$ At a discount rate of $3 \%$, the NPV reached a value of $34,896 \mathrm{CHF} \mathrm{ha}{ }^{-1}$ after 85 years in the selection stand and a value of $3002 \mathrm{CHF} \mathrm{ha}{ }^{-1}$ in the even-aged stand.

$\Rightarrow$ Calculated with harvesting costs and revenues from 2018 (Fig. 4b), the selection stand showed again higher NPVs. It reacheed a value of 23,460 $\mathrm{CHF} \mathrm{ha}{ }^{-1}$ at a discount rate of $1 \%$ after 85 years, whereas the even-aged stand recieved a value of $-29,984 \mathrm{CHF} \mathrm{ha}^{-1}$.

$\Rightarrow$ At a discount rate of $3 \%$, the selection stand showed a value of $9153 \mathrm{CHF} \mathrm{ha}^{-1}$ after 85 years and the even-aged stand reached a value of $-28,649$ CHF ha ${ }^{-1}$.

$\Rightarrow$ When comparing the $1 \%$ vs the $3 \%$ discounting rates for the even aged stand 2018, we can see the following: In the first years, the NPV with $1 \%$ discounting rate was much lower than that with $3 \%$. However, in the second half of the period they approached and reached about the same level after 96 years. This can be explained by the fact that the afforestation was expensive and the first thinnings were not profitable. These deficits became less negative through higher discount rates. Towards the end of the period, however, the harvest net revenues from thinning and final cut became positive: these positive values were smaller with $3 \%$ discounting than with $1 \%$. All in all, these effects canceled each other out.

$\Rightarrow$ Nowadays, even-aged stands are harvested using highly mechanised and cost-effective methods whenever possible. The harvesting costs for harvesters and forwarders could be easily calculated thanks to HeProMo. Under the mechanised scenario, the NPV of the even-aged stand achieved a value of $-10,564 \mathrm{CHF} \mathrm{ha}^{-1}$ at a $1 \%$ and a value of $-24,026 \mathrm{CHF} \mathrm{ha}{ }^{-1}$ at a $3 \%$ discount rate after 96 years. The modern rationalized harvesting methods therefore considerably improved the economic situation from $-27,125 \mathrm{CHF} \mathrm{ha}{ }^{-1}$ to $-10,564 \mathrm{CHF} \mathrm{ha}^{-1}$ at $1 \%$ and from $-28,649$ $\mathrm{CHF} \mathrm{ha}^{-1}$ to $-24,026 \mathrm{CHF} \mathrm{ha}^{-1}$ at $3 \%$ discounting.

$\Rightarrow$ While in the selection stand the mean stem volume per exploitation was $1-3 \mathrm{~m}^{3}$, in the evenaged stand it was less than $1 \mathrm{~m}^{3}$ even in older stands. This of course had a significant effect on the costs and revenues of timber harvest.

$\Rightarrow$ The net value at the end of the observation period showed striking differences (Table 4). The assets in the even-aged stand were concentrated in the final stock, which represents a high risk. In the case of the selction stand, on the other hand, the increase in value was continuously harvested. The value of the stand was therefore relatively low.

Overall, it is remarkable that the selection stand, although growing on a half as fertile site as the evenaged stand, still performed much better. The judgement, which stand is in advantage, has not changed 

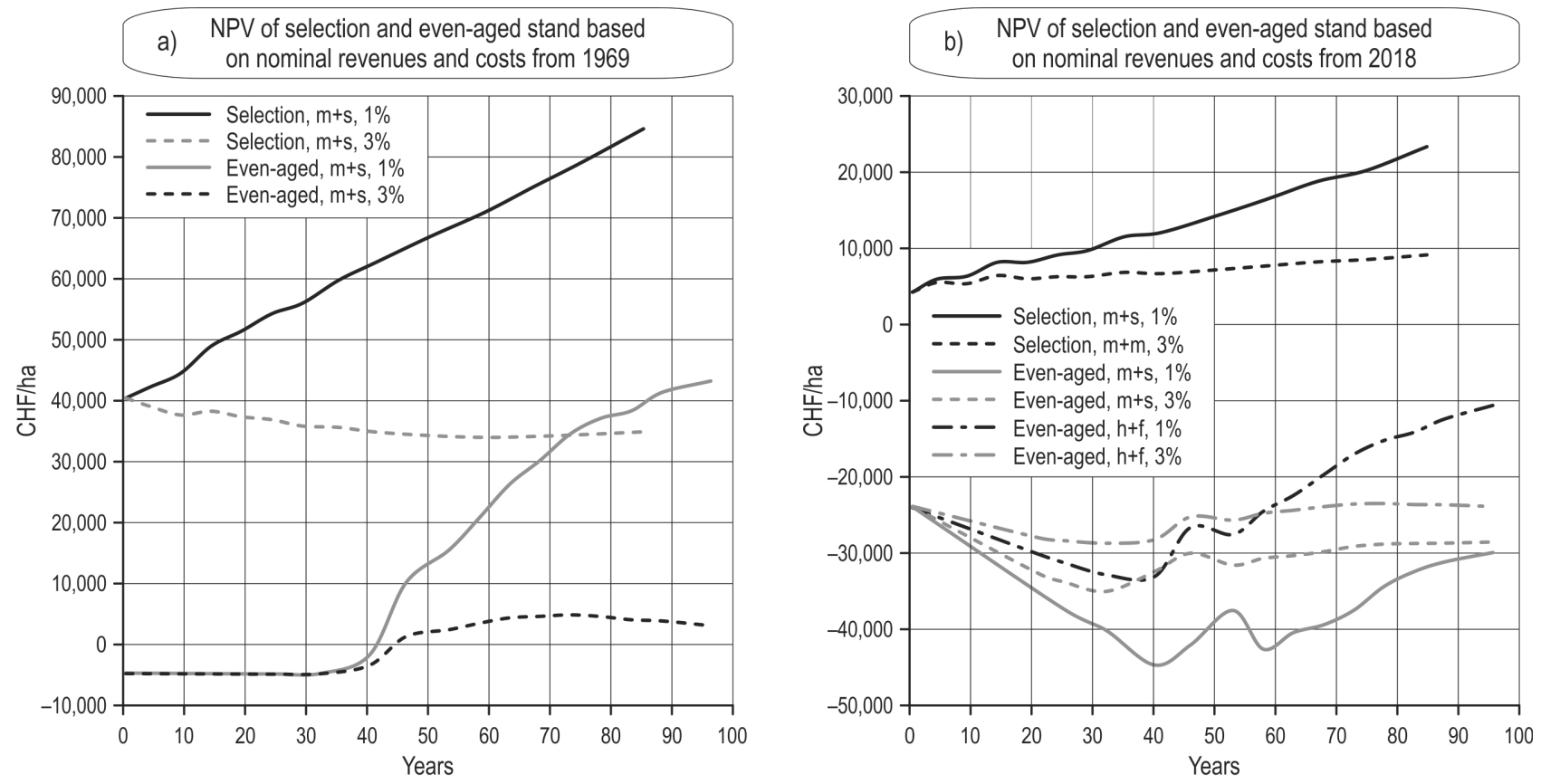

$m+s$ - indicates that the harvesting costs were calculated using the HeProMo models »motor manual felling « and "skidder « $h+f-$ indicates that the harvesting costs were calculated with the HeProMo models »harvester « and »forwarder«

The $\mathrm{x}$-axis means the age (years) of the forest in the case of the even-aged stand, and the period since the first inventory in the case of the selection stand

Fig. 4 Development of the net present value (NPV) in an even-aged and a selection stand at a 1\% and 3\% discount rate calculated with harvest models, costs and revenues from 1969 (a) and 2018 (b)

with the nominal cost and revenue estimates of 1969 or 2018, nor with the discount rates. On the basis of this real life example, one could assume financial advantages of the selection stand over the even-aged stand, as found by Schütz et al. (2012). An almost continuous profit is possible in selection stands, which gives their owners great flexibility. In comparison, even-aged stands in the high forest usually also incur regeneration costs. Moreover, even-aged stands are exposed to substantial risks. Knoke and Seifert (2008) show that nearly $50 \%$ of 100 -year-old spruce stands do not survive. With each year that passes, the risk of the even-aged stand being damaged increases in the course of unforeseen events, e.g. windthrow or insect infestation (Knoke and Seifert 2008). With all the advantages of selection stands, however, it should not be forgotten that only certain tree species (spruce, fir, beech, Douglas fir) can be considered for this strategy. Consequently, the selection system can only be applied in specific forest situations and regions of Switzerland or other countries.

It can be concluded that economic assessment is highly dependent on which cost and revenue approaches and which timber harvesting methods are used when making comparisons. The mechanisation of forest management has largely compensated increased harvesting costs and decreased timber prices. From today's perspective, the total value of even-aged stands compared to that of selection stands, at least

Table 4 The final value per hectare of the even-aged forest stand til age 96 and of the selection stand from the first inventory til the last inventory, i.e. after 85 years. The harvest net revenues refer to revenues and harvesting costs of the years 1969 and 2018. Additionally, the effect of a fully mechanised harvesting regime is presented for the even-aged stand in the year 2018

\begin{tabular}{|c|c|c|c|c|c|}
\hline \multicolumn{2}{|c|}{ Stand type } & \multicolumn{2}{c|}{ Even-aged stand (age 96 years) } & \multicolumn{2}{c|}{ Selection stand (after 85 years) } \\
\hline \multicolumn{2}{|c|}{ Year } & 1969 & 2018 & 1969 & 2018 \\
\hline \multirow{2}{*}{ Harvesting regime (harvest net revenues), CHF/ha } & Motor-manual felling and skidder & 111,561 & 36,126 & 32,272 & 2159 \\
\cline { 2 - 7 } & Harvester and forwarder & - & 55,509 & - & - \\
\hline
\end{tabular}


until the age of 85 , can only break even if rational harvesting techniques are deployed.

As indicated here, the SorSim assortment model offers a way to efficiently simulate timber sorting over entire rotations, or production periods, to whatever level of detail is required for addressing complex economic issues. Thus, the results can form the basis for strategic and scientific considerations of profitability.

\subsection{Challenges and Need for Further Research}

More accurate forecasts of timber revenues, an economically important factor, usually require a large investigative effort in the forest stands that are planned to be harvested. In addition, the quality of timber in standing trees can only be estimated through considerable effort. Thus, the DBH distribution of the stand to be felled is a decisive variable for assessing possible timber revenues. Tree height and the choice of the form quotient $\mathrm{d} 7 \mathrm{~m} / \mathrm{DBH}$ also plays an important role. In 2012-2013, WSL tested the accuracy of DBH, tree height and $\mathrm{d} 7 \mathrm{~m} / \mathrm{DBH}$ estimated with the SorSim simulator, using data on spruce trees included in the NFI and data on various tree species gathered during forestry practice. For spruce trees, the estimated volumes were largely consistent with the NFI values (volume functions, individual tree values). By contrast, the SorSim values obtained when the 'splines' stem form was applied were $10-15 \%$ lower than the yield table values presented by Badoux (1983). When using the function described by Lemm (1991), the estimated volume is roughly equivalent to that featured in the yield table.

The economic efficiency of selection forests compared to forests of even-aged trees has been investigated in numerous previous studies (see reviews by Hanewinkel (2002) and Knoke (2012)). Unlike evenaged forests, selection forest stands are economically attractive because a large percentage of high-quality stem wood with large dimensions can be harvested from them. In addition, there is evidence that the risk of biotic and abiotic disturbances is comparatively low in selection forests, owing to their complex stand structure and the high stability of their individual trees (Dvorak and Bachmann 2001, Hanewinkel 2001, Hanewinkel et al. 2014b). Moreover, timber harvesting costs are lower for selection forests because of the piece mass law (despite the limited possibility of mechanising the harvesting of trunk wood) and because no regeneration costs are incurred. However, other studies of real-life stands show that, depending on the revenue and cost situation, both types can perform equally well economically. A key prerequisite for such a comparison is the appropriate consideration of risk impact (Hanewinkel 2001, Hanewinkel 2002, Knoke and Seifert 2008).

In the future, SorSim will be developed further to enable not only optimisation of dimensions but also value optimisation in the context of sorting individual trees. This means that rather than sorting the strongest assortments first (Section 2.1.1), SorSim will sort each tree in a manner that enables the highest possible revenue to be obtained from it. This improvement will provide forest practitioners with the opportunity to optimally allocate harvesting interventions to meet the various customer demands.

SorSim can also be an important sub-component of higher-level decision support systems (DSSs) designed to improve overall forest management planning (Borges et al. 2014, Segura et al. 2014). If DSSs are intended to assess a forest economic development, models for quantifying timber harvesting costs and revenues are indispensable (Blattert and Lemm 2018).

\section{Conclusions}

We have described a simulator programme for sorting individual trees and entire stands into marketable timber products. The SorSim assortment simulator can calculate the timber revenues of different tree species or entire stands. Sorting in SorSim can be easily adapted to the situation in other countries.

SorSim is suitable for forestry practice because it quickly and reliably gives specific ideas about potential assortment yields and revenues in a timber marketing context. The additional value of the software lies in its calculation of contribution margins (harvest net revenues) in actual forest stands by linking with the HeProMo harvesting productivity models (Frutig et al. 2009). Importantly, SorSim has the potential to support the planning of short- to long-term forest management in an economical manner.

As our second example shows, the simulator is also a valuable support tool for scientists. Calculations or experiments can be carried out to identify and discuss possible consequences of supposed assumptions. SorSim offers the opportunity to reproduce historical decisions by assuming different assortment revenues and timber harvesting costs.

Overall, SorSim is a valuable tool for simulating and evaluating forest management strategies. It provides a quantitative basis that can be used to improve the economic performance of forest management. Value optimisation and optimisation to meet customer needs will be key goals in the future. The SorSim software and manual can be downloaded for free from 
WSL's website https://www.waldwissen.net/technik/ holzernte/kalkulation/wsl_sortierungssimulator/.

\section{References}

Altherr, E., Unfried, P., Hradetzky, J., Hradetzky, V., 1974: Statistische Rindenbeziehungen als Hilfsmittel zur Ausformung und Aufmessung unentrindeten Stammholzes. Teil I: Kiefer, Buche, Hainbuche, Esche, Roterle. Mitt. der FAVA, H. 61.

Anon., 2018: Jahresbericht 2017 Stadtforstamt Baden. Stadt Baden, Baden.

Badoux, E., 1979: Rindenprozente (Unveröffentlichte Tabelle aus der Dendrometrie-Vorlesung an der ETH Zürich).

Badoux, E., 1983: Ertragstafeln für die Fichte in der Schweiz. 3. Auflage (desgleichen für Tanne, Lärche und Buche). Eidgenössische Anstalt für das forstliche Versuchswesen (EAFV), Birmensdorf.

Blattert, C., Lemm, R., 2018: Ein multikriterielles Entscheidungssystem für die multifunktionale Bewirtschaftung von Wäldern auf forstbetrieblicher Ebene. Schlussbericht. Eidg. Forschungsanstalt WSL, Birmensdorf, $109 \mathrm{p}$.

Blattert, C., Lemm, R., Thees, O., Hansen, J., Lexer, M.J., Hanewinkel, M., 2018: Segregated versus integrated biodiversity conservation: Value-based ecosystem service assessment under varying forest management strategies in a Swiss case study. Ecological Indicators 95: 751-764. https://doi. org/10.1016/j.ecolind.2018.08.016

Blattert, C., Lemm, R., Thees, O., Lexer, M.J., Hanewinkel, M., 2017: Management of ecosystem services in mountain forests: Review of indicators and value functions for model based multi-criteria decision analysis. Ecological Indicators 79: 391-409. https://doi.org/10.1016/j.ecolind.2017.04.025

Borges, J.G., Nordström, E.M., Garcia-Gonzalo, J., Hujala, T., Trasobares, A., 2014: Computer-based tools for supporting forest management. The experience and the expertise worldwide. Report of Cost Action FP 0804 Forest Management Decision Support Systems (FORSYS).

Brassel, P., Lischke, H., (eds.) 2001: Swiss National Forest Inventory: Methods and Models of the Second Assessment. Swiss Federal Research Institute WSL, Birmensdorf.

Bürgi, P., Thomas, M., Pauli, B., Auer, N., 2018: Forstwirtschaftliches Testbetriebsnetz der Schweiz: Ergebnisse der Jahre 2014-2016. Bundesamt für Statistik (BFS), Neuchâtel.

Dvorak, L., Bachmann, P., 2001: Plenterwälder sind sturmfester. Wald Holz 9: 47-50.

Döbbeler, H., Albert, M., Schmidt, M., Nagel, J., 2002: BWINPro - Programm zur Bestandesanalyse und Prognose. Handbuch zur Version 6.1. Niedersächsische Forstliche Versuchsanstalt Abteilung Waldwachstum, Göttingen, 121 p.
EASAC, 2017: Multi-functionality and sustainability in the Eurpean Union's forests. EASAC policy report 32. Eurpean Academies' Science Advisory Council, 43 p.

Forest Europe, 2015: Meeting the Goals for European Forests and the European 2020 Targets for Forests. Report on the mid-term evaluation. Ministerial Conference on the Protection of Forests in Europe FOREST EUROPE.

Frutig, F., Thees, O., Lemm, R., Kostadinov, F., 2009: Holzernteproduktivitätsmodelle HeProMo - Kenzeption, Realisierung, Nutzung und Weiterentwicklung. In: Thees, O., Lemm, R., (eds.) Management zukunftsfähige Waldnutzung. Grundlagen, Methoden und Instrumente. vdf Hochschulverlag, Birmensdorf, Eidg. Forschungsanstalt WSL, 441-466.

FVA, 2013: Benutzerhandbuch Kalkulationsprogramm Holzernte - Entscheidungshilfe fuer Holzaufbereitung und -bringung, Holzvermarktung, Controlling und Waldbewertung, Version 8.0. Forstliche Versuchs- und Forschungsanstalt Baden-Wuerttemberg FVA, Freiburg.

Fürstenau, C., Badeck, F.W., Lasch, P., Lexer, M.J., Lindner, M., Mohr, P., Suckow, F., 2007: Multiple-use forest management in consideration of climate change and the interests of stakeholder groups. European Journal of Forest Research 126(2): 225-239. https://doi.org/10.1007/s10342-006-0114-x

Grundner, F., Schwappach, A., 1952: Massentafeln zur Bestimmung des Holzgehaltes stehender Waldbäume und Waldbestände, (Hrsg.) Schober, R. 10. Aufl. Hamburg und Berlin.

Hanewinkel, M., 2001: Neuausrichtung der Forsteinrichtung als strategisches Managementinstrument Allgemeine Forst und Jagdzeitung 172: 202-211.

Hanewinkel, M., 2002: Comparative economic investigations of even-aged and uneven-aged silvicultural systems: a critical analysis of different methods. Forestry: An International Journal of Forest Research 75: 473-481. https://doi. org/10.1093/forestry/75.4.473

Hanewinkel, M., Cullmann, D.A., Schelhaas, M.-J., Nabuurs, G.-J., Zimmermann, N.E., 2013: Climate change may cause severe loss in the economic value of European forest land. Nature Climate Change 3(3): 203-207. https://doi. org/10.1038/nclimate1687

Hanewinkel, M., Frutig, F., Lemm, R., 2014a: Economic performance of uneven-aged forests analysed with annuities. Forestry 87(1): 49-60. https://doi.org/10.1093/forestry/cpt043

Hanewinkel, M., Hummel, S., Cullmann, D.A., 2010: Modelling and economic evaluation of forest biome shifts under climate change in Southwest Germany. Forest Ecology and Management 259(4): 710-719. https://doi.org/10.1016/j.foreco.2009.08.021

Hanewinkel, M., Kuhn, T., Bugmann, H., Lanz, A., Brang, P., 2014b: Vulnerability of uneven-aged forests to storm damage. Forestry: An International Journal of Forest Research 87(4): 525-534. https://doi.org/10.1093/forestry/ cpu008 
Hansen, J., Nagel, J., 2014: Waldwachstumskundliche Softwaresysteme auf Basis von TreeGrOSS - Anwendung und theoretische Grundlagen. Universtitätsverlag Göttingen, 226 p.

Holm, S., Lemm, R., Erni, V., 2012: Handbuch Sortimentsimulator »SorSim « Version 2.0. Eidg. Forschungsanstalt für Wald, Schnee und Landschaft WSL, 43 p.

Härtl, F.H., Barka, I., Hahn, W.A., Hlásny, T., Irauschek, F., Knoke, T., Lexer, M.J., Griess, V.C., 2016: Multifunctionality in European mountain forests - an optimization under changing climatic conditions. Canadian Journal of Forest Research 46(2): 163-171. https://doi.org/10.1139/cjfr-20150264

Klemperer, W.D., 1996: Forest resource economics and finance. McGraw-Hill, New York, 551 p.

Knoke, T., 2009: Zur finanziellen Attraktivität von Dauerwaldwirtschaft und Überführung: eine Literaturanalyse I On the financial attractiveness of continuous cover forest management and transformation: a review. Schweizerische Zeitschrift fur Forstwesen 160(6): 152-161. https://doi. org/10.3188/szf.2009.0152

Knoke, T., 2012: The Economics of Continuous Cover Forestry. In: Pukkala, T., von Gadow, K., (eds.) Continuous Cover Forestry. Springer Netherlands, Dordrecht, 167-193.

Knoke, T., Seifert, T., 2008: Integrating selected ecological effects of mixed European beech-Norway spruce stands in bioeconomic modelling. Ecological Modelling 210(4): 487498. https://doi.org/10.1016/j.ecolmodel.2007.08.011

Lemm, R., 1991: Ein dynamisches Forstbetriebs-Simulationsmodell - Prognosen von betriebsspezifischen Waldentwicklungen, Waldschäden und deren monetäre Bewertung unter variablen Einflussgrössen. ETHZ. https://doi.org/10.3929/ ethz-a-000592268

Lemm, R., Erni, V., 2009: Bessere Nutzungs- und Allokationsentscheide mit dem Sortierungssimulator SorSim. In: Thees, O., Lemm, R., (eds.) Management zukunftsfähige Waldnutzung. Grundlagen, Methoden und Instrumente. vdf Hochschulverlag, Birmensdorf, Eidg. Forschungsanstalt WSL, 415-439.

Möhring, B., 2010: Optimierung forstlicher Produktion unter Beachtung von finanziellen Restriktionen (Optimisation of forest production under financial restrictions). Schweizerische Zeitschrift fur Forstwesen 161(9): 346-354. https://doi. org/10.3188/szf.2010.0346

Möhring, B., Rüping, U., 2008: A concept for the calculation of financial losses when changing the forest management strategy. Forest Policy and Economics 10(3): 98-107. https:// doi.org/10.1016/j.forpol.2007.06.004

Navarro, G.A., 2003: On 189 years of confusing debates over the König-Faustmann formula. Verlag Dr. Kessel, RemagenOberwinter, $221 \mathrm{p}$.

Niederer, R., Bill, M., 2015: Entwicklung der Rohholzpreise und der Lohnkosten in der Forstwirtschaft. Eine Zeitreihe von 1919/1939 bis 2014. Im Auftrag des Bundesamtes für Umwelt BAFU mit Unterstützung von Waldwirtschaft Schweiz WVS. Fachhochschule Nordwestschweiz, Hochschule für Wirtschaft, ICC Olten, 31 p.

Nölte, A., Meilby, H., Yousefpour, R., 2018: Multi-purpose forest management in the tropics: Incorporating values of carbon, biodiversity and timber in managing Tectona grandis (teak) plantations in Costa Rica. Forest Ecology and Management 422: 345-357. https://doi.org/10.1016/j.foreco.2018.04.036

Pukkala, T., 2016: Which type of forest management provides most ecosystem services? Forest Ecosystems 3(1): 9. https://doi.org/10.1186/s40663-016-0068-5

Rigling, A., Schaffer, H.P. (eds.), 2015: Forest Report 2015. Condition and Use of Swiss Forests. Federal Office for the Environment, Bern, Swiss Federal Institute WSL, Birmensdorf.

Rosset, C., Hässig, J., Thees, O., Lemm, R., Frutig, F., Bürgi, A., Hensler, U., Brang, P., 2009: Potenziale und Verfügbarkeit des Schweizer Holzes - Funktionsweise und erste Anwendung der dynamischen Waldholzverfügbarkeitskarte WVK. In: Thees, O., Lemm, R., (eds.) Management zukunftsfähige Waldnutzung. Grundlagen, Methoden und Instrumente. vdf Hochschulverlag, Birmensdorf, Eidg. Forschungsanstalt WSL, 157-190.

Schütz, J.-P., Pukkala, T., Donoso, P.J., von Gadow, K., 2012: Historical emergence and current application of CCF. In: Pukkala, T., von Gadow, K., (eds.) Continuous cover forestry. Springer, 1-28.

Segura, M., Ray, D., Maroto, C., 2014: Decision support systems for forest management: A comparative analysis and assessment. Computers and Electronics in Agriculture 101: 55-67. https://doi.org/10.1016/j.compag.2013.12.005

Seidl, R., Rammer, W., Jäger, D., Currie, W.S., Lexer, M.J., 2007: Assessing trade-offs between carbon sequestration and timber production within a framework of multi-purpose forestry in Austria. Forest Ecology and Management 248(1): 64-79. https://doi.org/10.1016/j.foreco.2007.02.035

Waldwirtschaft Schweiz, 2010: Schweizer Handelsgebräuche für Rohholz. Ausgabe 2010 edition. Lignum, Zürich. 
Authors' addresses:

Renato Lemm, PhD

e-mail: renato.lemm@wsl.ch

Stefan Holm, PhD

e-mail: stefan.holm@wsl.ch

Leo Bont, $\mathrm{PhD}$ *

e-mail: leo.bont@wsl.ch

Oliver Thees, $\mathrm{PhD}$

e-mail: oliver.thees@wsl.ch

Swiss Federal Institute for Forest, Snow

and Landscape Research WSL

Forest Resources and Management Unit

Zuercherstrasse 111

8903 Birmensdorf

SWITZERLAND

Clemens Blattert, PhD

e-mail: clemens.c.blattert@jyu.fi

University of Jyväskylä

Department of Biological and Environmental Science P.O. Box 35

40014 Jyväskylä

Received: November 11, 2018

FINLAND

Accepted: August 21, 2019

* Corresponding author 